Int. Arch. Allergy 1973;45:I-XIV

\title{
Contents, Vol. 45, 1973
}

Vol. 45,1973

International Archives of Allergy andAppliedlmmunology

Incorporating the Transactions of the Collegium Internationale Allergologicum

Founders:

P. Kallós, Helsingborg

Fred W. Wittich,

D. Harley, London

W. Löffler $\uparrow$, Zurich

Minneapolis, Minn.

Editore-in-Chief:

R. R. A. Coombs, Cambridge

P. Kallós, Helsingborg

Z. Trnka, Basel

H. C. Goodman, Geneve

F. Milgrom, Buffalo, N.Y.

G. B. West, Epsom

Contributing

E. L. Becker,

F. Hahn, Wittnau

H. Storck, Zurich

Editors:

Washington, D.C.

M. Hess, Bern

A. Szenberg, Melbourne

H. Bloch, Basel

Susan R. Hollán, Budapest

G. P. Talwar, New Delhi

W. E. Brocklehurst,

T. Inderbitzin, Bern

T. B. Tomasi, jr.,

Windlesham

H. Isliker, Lausanne 
Buffalo, N.Y.

A. Cerletti, Basel

E. A. Kabat,

G. Torrigiani, Geneve

B. Diamant, Copenhagen

New York, N.Y.

J. L. Turk, London

W. P. Faulk, Geneve

R. Keller, Zurich

E. R. Unanue, Boston,

M. Feldman, Rehovot

K. Ostrowski, Warszawa

Mass.

H. Fischer,

Ö. Ouchterlony, Göteborg

B. H. Waksman,

Freiburg-Zähringen

R. Panzani, Marseille

New Haven, Conn.

R. van Furth, Leiden

P. Perlmann, Stockholm

A. L. de Weck, Bern

P.G.H. Gell, Birmingham

M. Roitt, London

G. Wick, Wien

H. Gewurz, Chicago, Ill.

K. Rother, Heidelberg

G. A. Voisin, Paris

I. Glazer, Tel Aviv

D. S. Rowe, Lausanne

R. G. White, Glasgow

R. A. Good,

M. Simic, Belgrade 
Minneapolis, Minn.

E. Sork $\gamma$, Davos Platz

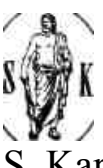

S. Karger $\cdot$ Basel $\cdot$ München $\cdot$ Paris $\cdot$ London $\cdot$ New York $\cdot$ Sydney

Contents

No. $1-2$

Transactions of the Collegium Internationale Allergologicum

9th Symposium in London, September 12-15, 1972

The Theoretical and Practical Aspects of Allergic Disorders I

Coombs, R. R. A. (Cambridge): The First Carl Prausnitz Memorial Lecture . . . 1

Itnmunological Aspects of Reaginic Allergy

Strannegård, Ö. (Göteborg): Regulatory Mechanisms in Reagin Synthesis ... 24

Malley, A.; Beacher, L., and Crossley, G. (Beaverton, Oreg.): The Isolation of

Two Human IgG Myeloma Proteins with Skin Fixing Properties on Mon

key Lung Tissue Like Human Reagin

26

Berrens, L. and Rijswijk-Verbeek, J. van (Utrecht): Inactivaíion of Complement

(C3) in Human Serum by Atopic Allergens 30

Girard, J. P.; Berger, F., and Hampai, A. (Geneva): Biochemical and Immuno-

logical Properties of Low Molecular Weight Constituents of Timothy

Pollen Antigen $\quad 40$

Mullan, N. A. (Betchworth): Immunological Properties of Carbohydrate and

Protein Fractions of Timothy Grass Pollens 43

Aalberse, R. C.; Reerynk-Brongers, E. E., and Vermeulen, E. (Amsterdam):

Rast-Inhibiting Factors in Human Serum 46

Aronsson, T. and Wide, L. (Uppsala): The Radioallergosorbent Test Used for

Characterization of Allergenic Extracts 50

Johansson, S. G. O.; Bennich, H., and Foucard, T. (Uppsala): Quantitation of IgE Antibodies and Allergens by the Radioallergosorbent Test, RAST... 55

Aas, K. and Belin, L. (Göteborg): Standardization of Diagnostic Work in Allergy 57

Pharmacological Aspects of Reaginic Allergy

Assem, E. S K. and Schild, H. O. (London): /?-Adrenergic Receptors Concerned

with the Anaphylactic Mechanism 62

Mongar, J. L.; Svec, P., and Foreman, J. C. (London): Anaphylactic Secretion

of Histamine in Relation to the Interaction of Phospholipids with Diva

lent Cations 70

Jasani, B.; Stanworth, D. R.; Mackler, B., and Kreil, G. (Birmingham): Stu

dies on the Mast Cell Triggering Action of Certain Artificial Histamine

Liberators 74

Taylor, W. A. (Stoke Court): The Effect of Disodium Cromoglycate and PGF3ct

on Acute Cutaneous Reactions of the Guinea Pig and Rat 82

Fullarton, J.; Martin, L. E., and Vardey, C. (Ware): Studies on the Inhibition

of Cellular Anaphylaxis $\quad 84$

Piper, Priscilla J. (London): Substances Released from Passively Sensitized

Human Lung Tissue During Challenge $\quad 87$ 
Eisen, V. and Loveday, C. (London): Intrinsic Activation of Plasma Kinin Forma tion and Complement 91

Contents III

Gillespie, Elizabeth and Lichtenstein, L. M. (Baltimore, Md.): Pharmacologic

Control of IgE-Mediated Histamine Release from Human Leukocytes . 95 Patterson, R. and

Kelly, J. F. (Chicago, Ill.): Cellular and Physiologic Studies of

Immediate-Type Respiratory Reactions $\quad 98$

Stechschulte, D. J. and Austen, K. F. (Boston, Mass.): Control Mechanisms of

Antigen-Induced Histamine Release from Rat Peritoneal Cells .... 110 Schmutzler, W. and

Derwall, R. (Aachen): Experiments on the Role of Cyclic

AMP in Guinea Pig Anaphylaxis 120

Fireman, P. (Pittsburgh, Pa.): Metabolic Abnormalities in Asthma - Decreased

Urinary Cyclic AMP 123

Basic Immunological Mechanisms

Karush, F. and Hornick, Carole L. (Philadelphia, Pa.): Multivalence and Affinity

of Antibody 130

Munder, P. G. and Modolell, M. (Freiburg): Adjuvant Induced Formation of

Lysophosphatides and Their Role in the Immune Response 133

Meacock, S. C. R. and Marsden, C. Hilary (Windlesham): The Effects of Adju

vants and Stress on the Production of IgE Antibody in Rats 136

Rose, N. R.; Kite, J. H., jr.; Vladutiu, A. O.; Tomazic, V., and Bacon, L. D.

(Buffalo, N.Y.): Genetic Aspects of Autoimmune Thyroiditis 138

Milgrom, F. (Buffalo, N.Y.): Studies on Surface Antigens of Mammalian Cells. . 150

Schneider, C. H. and Weck, A. L. de (Bern): Peptide Antigens for the Study of

Interactions Between Determinants, Antibodies and Immunologically

Active Cells 160

Brostoff, J. (London): Cellular and Humoral Effects of Hyposensitization in

Patients with Summer Hay Fever 162

Thompson, R. A. (Birmingham): Specific Antibodies in Allergic Subjects . ... 170

Immune Complexes, Complement and Autoimmunity

Steward, M. W.; Petty, R. E., and Soothill, K. F. (London): Low Affinity

Antibody - Its Possible Immunopathologic Significance 176

Soothill, J. F. and Steward, M. W. (London): The Relationship of Allergic

Disease to Immunodeficiency 180

Christian, C. L. (New York, N. Y.): Immune Complex Events in Connective

Tissue Disease 183

Lambert, P. H.; Bricteux, N.; Salmon, J., and Miescher, P. A. (Geneva): Dyna

mics of Immune Complex Nephritis during Antibody Excess 185

Maillard, J. L. and Voisin, G. A. (Paris): Non-Hemorrhagic Arthus Reaction and

Its Independence from Circulating Antibodies and Complement .... 190

Brown, D. L. and Lachmann, P. J. (London): The Behaviour of Complement and

Platelets in Lethal Endotoxin Shock in Rabbits 193

Donaldson, Virginia H. (Cincinnati, Ohio): Kinin Formation in Hereditary

Angioneurotic Edema (HANE) Plasma 206

Holborow, E. J. and Papamichail, M. (Maidenhead): Observations on Lymphocytes Bearing

Surface Immunoglobulin in Health and in Disease . . 210 
IV

Contents

Doniach, Deborah (London): The Relationship Between the Viruses Causing

Hepatitis and Autoimmunity in Liver Disease

214

Wright, R. (Southampton): Immunological Studies in Coeliac Disease

216

Amos, H. E. (London): Diagnosis of Allergic Drug Reaction

218

Lymphocyte Populations

Wekerle, H.; Lonai, P., and Feldman, M. (Rehovot): Diversity of T-Lympho-

cytes - Cell Receptors for Transplantation Antigens 234

Leuchars, Elizabeth; Davies, A. J. S., and Wallis, Valerie (London): Studies

on T-Cell Precursors 237

Parrott, Delphine, M. V.; Ferguson, Anne, and Sousa, Maria A. B. de (Glas

gow) : Factors Affecting the Traffic and Segregation of Lymphoid Cell Po

pulations 240

Denman, A. M. and Pinder, Margaret (Harrow): Induction of Antibody Synthe

sis in Cultures of Human Lymphoid Cells 249

Polak, L.; Frey, J. R., and Turk, J. L. (Basel): A Contribution to the Mechanism

of Induction of Tolerance to DNCB in Guinea Pigs 258

Asherson, G. L. and Allwood, G. G. (Harrow): Movement to Sites of Inflamma

tion and Non-Specific Cytotoxicity of T Lymphocytes Stimulated by

Antigen in vivo and Their Resemblance to Lymphocytes Stimulated with

Phytohaemagglutinin in vitro 262

Kano, S. and Bloom, B. R. (Bronx, N.Y.): Detection of Activated, Non-Dividing

T-Cells by the Virus Plaque Assay 272

Perlmann, P.; Perlmann, H., and Müller-Eberhard, H. J. (La Jolla, Calif.): Lymphocyte-Mediated

Cytotoxicity Induced by Humoral Antibodies. Mechanism of Induction and Surface Markers of

the Effector Cells ... 278

Henney, S. (Baltimore, Md.): Studies on the Mechanism of T Lymphocyte-Mediat

ed Cytolysis 281

Loewi, G. and Papamichail, M. (Maidenhead): Studies of Mononuclear Cells from

Inflammatory Joint Effusions 285

Mechanisms of Delayed Hyper sensitivity

Trnka, Z.; Hay, J. B., and Lachmann, P. J. (Basel): Production of MIF and

Mitogenic Factor in vivo 292

Pick, E. and Manheimer, Shoshana (Tel-Aviv): The Mechanism of Action of

Macrophage Migration Inhibitory Factor (MIF) 295

Cordier, G.; Roux, C, and Revillard, J. P. (Lyon): Effect of Some Immuno-

suppressive Agents on Blastogenesis and Target-Cell Lysis in vitro . . 299

Glauser, M. P. and Frei, P. C. (Lausanne): Rosette-Forming Cells and MIF-

Producing Cells in Penicillin Allergies

304

Maini, R. N.; Roffe, L. M.; Magrath, I. T., and Dumonde, D. C. (London):

Standardization of the Leucozyte Migration Test 308

Marsman, A. J. W. and Van der Hart, Mia (Amsterdam): Migration Inhibition

Experiments with Mixtures of Human Lymphocytes and Guinea Pig

Peritoneal Exudate Cells $\quad 322$ 
Morlly, J. and Williams, T. J. (London): Pharmacological Properties of a Propos ed Mediator of Delayed Hypersensitivity Reactions 326

Contents

$\mathrm{V}$

No. 3

Schumann, G.; Schnebli, H. P., and Dukor, P. (Basel): Selective Stimulation of Mouse Lymphocyte Populations by Lectins 331

Lycke, E. and Roos, B.-E. (Göteborg): Brain Monoamines in Guinea Pigs with Experimental Allergic Encephalitis 341

Beng, Chay-Giap; Chan, Gim-Leong; Simons, Malcolm J., and Lau, Kam-Seng (Kuala Lumpur): Semi-Quantitation of Serum IgE by Counter-Immunoelectrophoresis 352

Jankovic, B. D. and Isakovic, Katarina (Belgrade): Neuro-Endocrine Correlates of Immune Response. I. Effects of Brain Lesions on Antibody Production, Arthus Reactivity and Delayed Hypersensitivity in the Rat 360

Isakovic, Katarina and Jankovic, B. D. (Belgrade): Neuro-Endocrine Correlates of Immune Response. II. Changes in the Lymphatic Organs of Brain-Lesioned Rats 373

Bundschu, D.; Bernauer, W., and Filipowski, P. (Freiburg i.Br.): Investigations on the Catecholamine Release in Anaphylactic, Anaphylatoxin, and

Histamine Shock of Guinea Pigs 385

Leguit, P., jr.; Feltkamp, T. E. W.; Van Rossum, A. L.; Van Loghem, Erna, and Eijsvoogel, V. P. (Amsterdam): Immunological Studies in Burn Patients.

III. Autoimmune Phenomena 392

Ceska, M. (Wien): Column Chromatography of Allergens and Assessment of Their Activities by the Paper Disc Radioallergosorbent Method 405

Ceska, M.; Ponterius, G., and Soininen, K. (Wien): Enzymatic Hydrolysis of Allergens and Assessment of the Remaining Allergenic Activities by the Paper Disc Radioallergosorbent Method 417

Leslie, Gerrie A. and Martin, Louis N. (New Orleans, La.): Suppression of Chicken Immunoglobulin Ontogeny by F(ab')2 Fragments of Anti- $\mu$ Chain and by Anti-L Chain 429

Haddad, Zack H. and Gillman, Sherwin A. (Los Angeles, Calif.): Disodium Cromoglycate and Human Reagin (IgE) Mediated Reactions. Effect on Wheal and Flare Skin Reactions and Histamine Release from Rat Mast Cells in vitro 439

Brandt, R.; Ponterius, G., and Yman, L. (Uppsala): The Allergens of Cat Epithelia and Cat Serum. Comparative Studies Based on the Radioallergo sorbent Technique (RAST) 447

Wislöff, F. and Fröland, S. S. (Oslo): Studies on the Cytotoxic Activity of $\mathrm{Hu}$ man Lymphoid Cells Activated by Concanavalin A 456

Davies, G. E. and Evans, D. P. (Macclesfield): Studies with Two New Phosphodiesterase Inhibitors (ICI 58, 301 and ICI 63, 197) on Anaphylaxis in

Guinea Pigs, Mice and Rats 467

No. 4 
Andersen, Paul; Nisengard, Russell, and Beutner, Ernst H. (Buffalo, N.Y.): Quantitative Studies of Immunofluorescent Staining. V. Analysis of Unwanted Staining of Tissues 479

VI

Contents

Callaghan, O. H.; Spitzer, R.; Kaplan, M. A., and Leija, J. G. (Chicago. Ill.): Uptake of Carbohydrate by Polyribosomes during the Immune Response to Ragweed Antigen 488

Dineen, J. K.; Kelly, J. D., and Love, R. J. (Glebe): The Competence of Lympho cytes Obtained from Immune and Non-Immune Donors to Cause Expul sion of Nippostrongylus brasiliensis in the Rat (DA Strain) 504

Chase, Merrill W. and Maguire, Henry C, jr. (New York, N.Y.): Studies on the Sensitization of Animals with Simple Chemical Compounds. XIV. Further Studies on Sensitization of Guinea Pigs with Picric Acid ... 513

Artis, W. M.; Artis, P. A., and Blazkovec, A. A. (Madison, Wise): Effects of Heterologous Antiserum Ig on Function of the Reticuloendothelial System. I. Vascular Clearance and Localization of Labeled Heterologous Erythrocytes in Guinea Pigs Treated with Immune Ig 543

Artis, P. A.; Artis, W. M., and Blazkovec, A. A. (Madison, Wise): Effects of Heterologous Antiserum Ig on Function of the Reticuloendothelial System. II. The Phagocytic Capacity of Guinea Pig Peritoneal Macrophages following Treatment in vitro with Immune Ig 554 Bluestone, Rodney; Goldberg, Leonard S.; Kalmanson, George M., and Guze, Lucien B. (Los Angeles, Calif.): Systemic and Urinary Immune Response in Experimental E. coli Pyelonephritis of Mice 571 Wacker, W. B. and Kalsow, Carolyn M. (Louisville, Ky.): Autoimmune UveoRetinitis in the Rat Sensitized with Retina Photoreceptor Cell Antigen . 582 Coffey, Ronald G. and Middleton, Elliott, jr. (Denver, Colo.): Release of Histamine from Rat Mast Cells by Lysosomal Cationic Proteins. Possible Involvement of Adenylate Cyclase and Adenosine Triphosphatase in Pharmacologic Regulation 593

Weisbart, R. H.; Cunningham, J. E.; Bluestone, R., and Goldberg, L. S. (Los Angeles, Calif.): A Modified Agarose Method for Detection of Migration Inhibitory Factor and Delineation of Its Antigen Dependency 612 Yoshida, H.; Kasukawa, R.; Yoshida, T., and Kano, K. (Buffalo, N.Y.): Skin Reactions Induced by Sera of Patients with Monoclonal IgG Gammapathy 620

Milgrom, Felix; Kano, Kyoichi, and Fjelde, Audrey (Buffalo, N.Y.): Studies on Heterophile Antigen in Lymphoma and Leukemia Spleens by Means of Absorption of Infectious Mononucleosis Sera

Book Reviews 638

News Item 638

No. 5

Wacker, W. B. (Louisville, Ky.): Experimental Allergic Uveitis. Studies on Characterization and Isolation of the Pathogenic Retina Antigen . . 639 
Branefors-Helander, Paula (Göteborg): Serological Studies of Haemophilus influenzae. IV. The Antibody Response in Rabbits against Capsular and $\mathrm{O}$ Antigens of $\mathrm{H}$. influenzae 657

Contents

VII

Klassen, J.; Kano, K.; Milgrom, F.; Menno, A. B.; Anthone, S.; Anthone, R.; Supulveda, M.; Elwood, C. M., and Andres, G. A. (Buffalo, N.Y.): Tubular Lesions Produced by Autoantibodies to Tubular Basement Membrane in Human Renal Allografts 675 Brostoff, Jonathan; Freedman, A., and Roitt, I. M. (London): Leucocyte Migration Inhibition to Mycoplasma fermentans in Patients with Rheu matoid Arthritis 690 Assem, E. S. K. and McAllen, Monica K. (London): Inhibition of Allergic Reac tions by Cromoglycate and by AH 7079 in Patients with Allergic Airway Disease 697

Assem, E. S. K. (London): Inhibition of Allergic Reactions by Cromoglycate and by a New Series of Compounds (AH 6556, AH 7079 and AH 7725) . 708 Glaister, J. R. (Edinburgh): Factors Affecting the Lymphoid Cells in the Small Intestinal Epithelium of the Mouse 719

Snippe, H.; Bruijnzeel, P. L. B., and Willers, J. M. N. (Utrecht): Effects of Immunosuppressive Treatment on the in vitro Activity of Mouse Lym phoid Cells after Stimulation by PHA and Allogeneic Cells 731

Doyle, J. J. (Glasgow): Homocytotropic Antibodies Induced in Calves by In fection with Fasciola hepatica 744

Doyle, J. J. (Glasgow): Skin Hypersensitivity Reactions Induced in Calves by Ex perimental Infections with Fasciola hepatica 752

Dineen, J. K. and Kelly, J. D. (Glebe): Expulsion of Nippostrongylus brasiliensis from the Intestine of Rats: the Role of a Cellular Component Derived from Bone Marrow 759

Kelly, J. D.; Dineen, J. K., and Love, R. J. (Glebe): Expulsion of Nippostrongy lus brasiliensis from the Intestine of Rats: Evidence of a Third Compo nent in the Rejection Mechanism 767 Kind, Leon S. and Macedo-Sobrinho, Braz (Halifax): Reaginic Antibody Formation in Mice Injected with Rabbit Anti-Mouse Thymocyte Serum. 780 Sweeney, W. Timothy and Seibel, Hugo R. (Richmond, Va.): Histamine Release from Peritoneal Mast Cells of Tumor Susceptible Rats following Periods of Tumor Growth and Sensitization with Tumor Antigen and B. pertussis 789

No. 6

Taylor, W. A. and Roitt, I. M. (London): Effect of Disodium Cromoglycate on Various Types of Anaphylactic Reaction in the Guinea Pig 795

Ceska, M. and Brandt, R. (Uppsala): Ultracentrifugation Patterns of Allergens in Sucrose Gradients and Assessment of Their Activities by the Paper

Disc Radioallergosorbent Method 808

Ceska, M. and Ponterius, G. (Uppsala): Study of the Nature of the Binding Sites

of Some Allergens Interacting with IgE 819

Glaister, J. R. (Edinburgh): Some Effects of Oral Administration of Oxazolone 
to Mice 828

Glaister, J. R. (Edinburgh): Autoradiographic Studies of Lymphoid Cells in the Small Intestinal Epithelium of the Mouse 844

VIII Contents

Glaister, J. R. (Edinburgh): Light, Fluorescence and Electron Microscopic

Studies of Lymphoid Cells in the Small Intestinal Epithelium of Mice . 854

Diaz Gill, Gustavo A.; Beutner, Ernst H., and Eisenberg, Richard B. (Buffalo,

N.Y.): Quantitative Studies of Immunofluorescent Staining. VI. Defined

Complement Immunofluorescent Staining for Antinuclear Antibodies

in Systemic Lupus and Other Collagen Diseases $\quad 868$

Ranadive, N. S.; Sajnani, A. N.; Alimurka, Krys, and Movat, H. Z. (Toronto):

Release of Basic Proteins and Lysosomal Enzymes from Neutrophil

Leukocytes of the Rabbit $\quad 880$

Schwartz, Howard J. and Bennett, Bruce (Cleveland, Ohio): The Differential

Effect of Acetylsalicylic Acid on in vitro Aggregation of Platelets from

Normal, Asthmatic and Aspirin-Sensitive Subjects 899

Whang, H. Y.; Loza, U.; Neter, E., and Milgrom, F. (Buffalo, N.Y.): Gel

Precipitation of Common Enterobacterial Antigen by Its Antibody . . 905

Ashworth, L. A. E. and Maclennan, A. P. (Salisbury): Immunological Tolerance

to Erwinia carotovora L-Asparaginase

915

Richter, Wolfgang (Uppsala): Built-in Hapten Inhibition of Anaphylaxis by the

Low Molecular Weight Subfractions of a B 512 Dextran Fraction of

Mw 3,400 930

Bryant, B. J.; Shifrine, M., and McNeil, Carla (Davis, Calif.): Cell-Mediated

Immune Response in the Developing Dog 937

News Item 943

Erratum 943

Author Index 944

S. Karger · Basel · München · Paris · London · New York · Sydney Arnold-Böcklin-Strasse 25, CH-4011 Basel (Switzerland)

All rights, including that of translation into other languages, reserved.

Photomechanic reproduction (photocopy, microcopy) of this volume or parts thereof

without special permission of the publishers is prohibited.

(C) Copyright 1973 by S. Karger AG, Verlag für Medizin und Naturwissenschaften, Basel Printed in Switzerland by National-Zeitung AG, Basel 